\title{
The Indigenization Of Business Ownership In An Emerging Market: Doing Business In South Africa
}

John Luiz, (Email: jluiz@uj.ac.za), University of Johannesburg, South Africa Roberto Gaspari, University of Johannesburg, South Africa

\begin{abstract}
Black economic empowerment (BEE) has transformed the South African economic and business environment, and continues to be one of the most important issues a company has to deal with in doing business in South Africa. The indigenization of ownership is also developing as a concern in several other emerging markets particularly in Latin America. This research focuses on BEE issues within the small medium enterprises (SMEs) sector of the engineering industry. The research set out to identify the issues which were considered to be important for the successful implementation of BEE. A significant finding was the importance of upfront planning and setting of objectives prior to implementation of BEE initiatives. The research also found a very low level of satisfaction with the outcomes of BEE initiatives. The findings of this research can prove to be valuable for policymakers and business as they review the progress made towards achieving the broader objectives of indigenization and the costs of doing business in such an environment.
\end{abstract}

Keywords: Black economic empowerment, indigenization of ownership, South Africa, doing business in emerging markets, small enterprises

\section{Introduction}

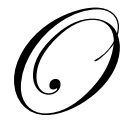

n 27 April 1994, all South African citizens were permitted to vote in the country's first democratic elections; an event that resulted in the election of the first democratic government, headed up by the African National Congress (ANC). This momentous occasion also spawned the start of dramatic political and economic changes in South Africa, at a time when the world was welcoming South Africa back into the global community. The process of political and economic transformation has still not yet fully run its course, with change remaining a part of the current political and economic environment.

The ANC has had to deal with conflicting social and economic objectives, particularly as South Africa has had to adjust to a rapidly changing international environment brought on by economic globalisation, a World Trade Organisation free trade regime and resulting enhanced competition (Mabert, Soni \& Venkataramanan, 2001). Despite these pressures, government has a commitment to its constituency to alleviate poverty and address disparities in the distribution of wealth, and facilitating the creation of a middle class that is representative of the demographics of the country and which will advance its socio-economic development. In other words, government needs to address the legacy of apartheid which resulted in the economic and political disenfranchisement of the majority of South Africans.

In an attempt to address these diverse economic and social issues, the government in 1996 introduced a strategy called GEAR (growth, employment, and redistribution), aimed at restructuring the economy. GEAR was successful in improving economic performance and fiscal discipline, a feat applauded by international economists; however, social disparities nevertheless remained and the wealth of the nation still remained in the hands of the minority. In response to this perceived failure, government introduced a black economic empowerment (BEE) policy and targets that all businesses were required to meet to promote the indigenization of ownership within South 
Africa: "It is aimed at redressing the imbalances of the past by seeking to substantially and equitably transfer and confer the ownership, management and control of South Africa's financial and economic resources to the majority of its citizens. It seeks to ensure broader and meaningful participation in the economy by black people to achieve sustainable development and prosperity." (Black Economic Empowerment Commission, 2001:11).

The government's decision to utilise BEE as its primary tool for enabling participation of the black majority in the mainstream economy has so far created both indecision and anxiety amongst investors and companies. FDI has suffered and South Africa has thus far proved an under-performer in attracting FDI, which stands at $2.2 \%$ of the national GDP (EIU, 2005a). This uncertainty has also resulted in a lack-lustre impact on unemployment rates which currently stand at around $26 \%$ and disproportionately affect the black population which again reinforces their economic exclusion.

The purpose of the current research is to create a better understanding of the issues affecting the implementation of BEE and its broader objectives, as represented by the Broad-based Black Economic Empowerment Act (2003), within the SMEs located in the engineering manufacturing sector. Such an understanding should create an opportunity for policymakers, businesses, investors and relevant stakeholders to refine their strategies and find a way of making this work for them.

\section{The Challenge Of The Indigenization Of Ownership: A Review}

The discussion about the role that government should play in addressing the economic inequalities of whites and blacks in South Africa continues well after a decade following the political transition. Some argue (Mangaliso and Nkomo, 2001) that young democracies like South Africa need legislative intervention, while mature economies, like that of the USA, can afford to do without government interference.

By early 2000, the newly re-elected government of the ANC had identified the shortcomings of the GEAR strategy and had embarked on a more prescriptive strategy of redistribution. This approach is supported by Sethi (2001:27), who states that "without BEE, growth and prosperity in South Africa cannot be sustained". The first intervention by government was the Preferential Procurement Policy Framework Act (2000), which outlined the criteria that all government, parastatal and government-owned agencies should apply when awarding contracts. The aim of the policy was to advance the development of SMEs and historically disadvantaged individuals (HDI): to promote the role of women and physically handicapped people; to create new jobs; to promote local enterprises in designated provinces; and to support local products. The policy was instrumental in sending a clear message to businesses that they needed to transform. However, it was only in 2002, when government leaked the fact that 51\% of mining companies had to be sold to blacks within a ten-year timeframe that the business community and investors realised the seriousness of government's commitment to transformation and in one day millions of dollars of stock were wiped off the Johannesburg Securities Exchange (JSE) (Robinson, 2004). This resulted in a flurry of negotiations with government and revised targets on equity ownership were established, including the formation of the first BEE charter.

The new impetus in BEE transformation focused on equity deals and a target of $26 \%$ was established in the market based on the mining charter. Critics charged that BEE was enriching a small elite, all politically connected to the ruling government. In support of their claim they cited the fact that in 2003, $80 \%$ of the value of the 10 largest transactions involved just three men, Cyril Ramaphosa, Tokyo Sexwale, and Patrice Motsepe. As a result of mounting pressure regarding the shortfalls of the BEE policy, government introduced the most significant piece of BEE legislation to date, the Broad-Based Black Economic Empowerment Act (2003). The B-BBEE Act emphasised that BEE not only consisted of equity ownership but also of human resource and skills development, employment equity in the workplace, preferential procurement and social and economic investment.

The BEE policy adopted by the government is made up of various Acts that work in synergy to achieve the objectives of BEE: 
- $\quad$ The Employment Equity Act (1998) was also the first Act to prescribe to companies that they must remove all forms of discrimination and start to put plans in place to transform their composition to reflect the demographics of the country.

- $\quad$ The Competition Act (1998) makes provision for the relaxing of anti-competitive practices, if they promote the competitiveness of black-owned and controlled business.

- $\quad$ The Skills Development Act (1998) and the Skills Development Levies Act (1999) are important in ensuring that a transfer of skills and development of skills occur in the designated sectors.

- The Preferential Procurement Policy Framework Act (2000) introduces the concept of adjudicating contracts, as well as the rules for such adjudication, based on an 80/20 or 90/10 principle, where either $80 \%$ or $90 \%$ of the contractual price is evaluated, with the balance being evaluated in terms of equity ownership. The Act is only enforceable in government, parastatal and government-owned agencies.

The B-BBEE Act does not specify how companies should go about achieving BEE, but does allow for publication of codes of good practice and industry-specific charters for the guidance of companies. Companies without an industry- specific BEE charter should use the guiding principles of the codes of good practice published by the Department of Trade and Industry (DTI). In particular, the DTI's scorecard should be used as a measurement of BEE compliance. Table 1 illustrates the DTI's B-BBEE scorecard.

Table 1: The DTI's BEE scorecard

\begin{tabular}{|c|c|c|}
\hline BEE elements & Weighting & Targets \\
\hline \multicolumn{3}{|l|}{ Direct Empowerment } \\
\hline Equity Ownership & $20 \%$ & $25 \%+1$ vote \\
\hline Management & $10 \%$ & $50 \%$ of executive management \\
\hline \multicolumn{3}{|c|}{ Human Resources Management } \\
\hline Employment Equity & $10 \%$ & $50 \%$ of staff across all levels \\
\hline Skills Development & $20 \%$ & $\begin{array}{l}3 \% \text { of payroll on skills development } \\
\text { spend }\end{array}$ \\
\hline \multicolumn{3}{|l|}{ Indirect Empowerment } \\
\hline Preferential Procurement & $20 \%$ & $50 \%$ of eligible procurement \\
\hline Enterprise Development & $10 \%$ & $1 \%$ of profit before tax \\
\hline \multicolumn{3}{|c|}{ Residual (corporate social investment) } \\
\hline To be determined by Sector & $10 \%$ & $1 \%$ of profit before tax \\
\hline Total Score & $100 \%$ & \\
\hline
\end{tabular}

The intended outcomes of BEE are broad and go beyond the measurement of financial return, as they include both social outcomes and political outcomes. It is thus very difficult to pin down a definition of success that objectively can conclude whether the BEE policies have been successful. Decades could pass before the first impact of policies on social structures is seen although its effect of doing business in South Africa is immediate. For example, $74 \%$ of American companies cite BEE policies as the primary reason for their not investing in South Africa because of the dilution of ownership (Masland, 2005).

\subsection{The Importance Of The Black Middle Class For South Africa?}

The importance of an established representative middle class is fundamental to the successful socioeconomic outcome of any nation. As early as $306 \mathrm{BC}$, Aristotle showed awareness of this truth, when he noted, "Thus it is manifest that the best political community is formed by citizens of the middle class, and that those states are likely to be well administered, in which the middle class is large.... where the middle class is large, there are least likely to be factions and dissention" (Easterly, 2001). 
More recently, Easterly's (2001) empirical study concurs with Aristotle's thoughts and conclusively shows that a high share of income for the middle class, together with a low level of ethnic divisions, is conducive to increased income levels and increased economic growth. This, in turn, leads to higher education levels across the population; improved health care; increased investment in infrastructure; improved economic policy; decreased political instability; reduced risks of civil war; reduced risk of ethnic minorities at risk; increased social modernisation; and an increased level of democracy. A consensual society favours economic growth in terms of future production as a means of redistribution rather than favouring the redistribution of existing assets; this has been evidenced by the demise and downfall of the Zimbabwean economy.

Randall (1996:663), however, is very sceptical of governmental attempts to build a Black middle class in South Africa, and warns that "in place of a self standing, viable capitalist class, an unproductive group of pseudo capitalists has emerged, dependent on political connections and rent seeking activities for their survival". Indigenisation policies pursued in Nigeria during the 1970s failed to empower African entrepreneurship. Multinational corporations, in an attempt to keep their Nigerian partners out of the day-to-day management of the companies, were appointing sleeping partners with stature and money (Randall, 1996). The beneficiaries of this policy were political heavyweights who manipulated the bureaucracy and offered protection for a share in the profits. Guest (2004:10) warns that the insidious side effect of BEE policy has been "the sort of cronyism that has wrecked the rest of Africa". The counter argument is that the empowerment beneficiaries will act as agents of transformation and act as role models (Guest, 2004). This practice, as adopted in South Africa, is commonly referred to as 'fronting'. Randall (1996) warns that South Africa is heading for the same fate as the rest of Africa, should it not ensure adequate transfer of skills. Business has opted out by offering 'soft positions', which are not considered core to the business to BEE incumbents in the realm of human resources and public relations.

A recent opinion poll found that no less than $65 \%$ of black people and $70 \%$ of other population groups were found to believe that the main beneficiaries of government economic policy are 'crony capitalists', politically well connected, rich businesspeople, as well as officials and politicians. In other words, there is no real consensus on whether or not government is succeeding in creating a new affluent black middle class (EIU, 2005c).

Randall (1996) proposes that there are two primary reasons why companies introduce BEE: firstly, companies that want to expand their markets to incorporate the black market implement BEE policy and, in particular, affirmative appointments in order to leverage the knowledge of the black appointments in developing this new market; secondly, companies implement BEE policies when they require political capital and influence in order to secure existing or new business for which BEE is a requirement.

Despite the warnings sounded by Randall (1996), he does identify significant differences that could favour the successful implementation of BEE in South Africa relative to other examples. These include the realisation by whites of the inevitable transfer of economic wealth to other racial groups in order to reflect the demographics of the country; extensive promotion of BEE policy by the policy-making regime; mobilisation against 'fronting' by prominent politicians and trade unions, and the relative sophistication of the South African economy, banking sector and infrastructure, allowing for multiple entry points into the economy for BEE companies.

\subsection{Global Empowerment Lessons}

Nigeria, Kenya and South Africa are not unique in their attempt to address economic disparities by means of the adoption of economic empowerment policies: Brazil and Malaysia have both adopted some form of empowerment policies too. Interestingly enough, their empowerment policies have met with the same controversial socio-political debate that South Africa is currently experiencing around the issue of BEE.

Of particular importance for South Africa is the lessons that can be learned from the Malaysian empowerment experience, as the consequence of empowerment policy implemented in the early 70 s can now be evaluated after a period of more than thirty years. 


\subsubsection{The Case Of Brazil}

Brazil is known to have one of the largest economic discrepancies between the rich and poor of any country. The majority of the rich are white European immigrants who have benefited from policies that benefited neither the Afro-Brazilians nor the indigenous people. The abolition of slavery in 1888 left the Afro-Brazilians at a complete disadvantage with respect to the whites, the legacy of which still remains today (Osava, 2006). The Brazilian government, under much social pressure, has proposed two draft laws promoting the marginalised ethnic groups, increasing the number of Afro-Brazilians hired as public employees, and introducing mechanisms to foster their advancement in their careers, as well as incentives for companies to employ and award managerial positions to Afro-Brazilians (Osava, 2006). The structure and form of the policies proposed for Brazil are very similar to those advanced by the South African government. However, despite equity ownership not yet having been targeted by the Brazilian government, the debate is heated, with the case both for and against the implementation highlighting similar issues.

\subsubsection{The Case Of Malaysia}

The differences between the various ethnic groups in the early 1970s were vast. In education Malay students comprised only $43 \%$ of all students at university, and the comparative percentage was even less in the sciences. In employment the majority of professional, technical and managerial positions were held by Chinese. Ownership of business was primarily in the hands of foreign entities (62\%), with the Chinese owning $22.8 \%$ and Indians less than $1 \%$, but the majority Malays only owned $1.5 \%$. Income disparities were also high, with an average monthly income for Malays of \$70, $\$ 122$ for Indians and \$158 for the Chinese; as a result, more than 65\% of Malays were living below the poverty line, compared to $26 \%$ of the Chinese (Klitgaard \& Katz, 1983).

The coalition government prior to 1971 had directed its policies towards rapid economic growth and measures directed towards the rural poor who were Malays, with their aim being to remove the existing ethnic inequalities. This approach is similar to that for the adoption of GEAR in South Africa; unfortunately, as was the case in South Africa, the level of inequality remained unacceptably high. This unhappiness culminated in the worst ethnic violence in the country's history; as a consequence, the Malay government introduced a New Economic Plan (NEP), primarily aimed at correcting economic imbalances between the various ethnic groups.

The NEP introduced policies that brought in the following reforms:

- $\quad$ Education: University admission was no longer solely based on academic qualification, but quotas were imposed and ethnic preference was given to those seeking financial assistance.

- $\quad$ Employment: A 40\% Malay employment quota was instituted in all commercial firms, which is essentially the equivalent of that instituted in the South African affirmative action programme.

- Credit: Commercial banks were encouraged and pressurised to increase credit lines to Malays and government organisations were mandated to facilitate access to capital for Malays.

- Ownership: The Malaysian government took ownership equity one step further than the South African government, by legislating that any new business created had to have at least 30\% Malay ownership equity.

- Government procurement: Quotas were established for Malay suppliers of various goods, which in some government departments, was stipulated to be as high as $30 \%$ of contracts awarded. South Africa has a similar policy in place, as legislated by the Preferential Procurement Framework Act (2000).

Klitgaard and Katz (1983) reviewed the progress made towards achieving the objectives of reducing racial inequality a decade later. Malay ownership increased, but primarily due to public agencies investing on behalf of the Malay people. Absolute growth in ownership was much larger for other ethnic minority groups. Distribution of income improved only marginally across the diverse ethnic groups. Despite the moderate success achieved by the Malaysian empowerment policies, the real achievement lay in the fact that there was no further inter-ethnic conflict during the period of implementation. Klitgaard and Katz (1983) attribute the dramatic decrease in conflict to two primary factors: firstly, the political skill of the leaders; and secondly, the period of surging economic growth that left the Chinese minority with the same proportion of wealth as it had experienced before the implementation of 
empowerment policies. South Africa finds itself in a similar situation, where strong political leadership and a decade of strong economic growth has left the white minority in a situation where they are not worse off than before the implementation of BEE policy.

The controversy and debate around whether the NEP in Malaysia has been successful continues. There is now some evidence that a culture of cronyism has been engendered, as the beneficiaries turned out not to be struggling Malay entrepreneurs, but rather former officials of the Ministry of Trade (EIU, 2005b). This unfortunately repeats the experiences found elsewhere around the world when analogous policies were put in place and indeed there is some confirmation for a similar pattern emerging in South Africa.

\section{Survey Of SMES In Engineering Sector}

This research aims to measure the level of satisfaction within the SMEs in the engineering manufacturing industries regarding the implementation of BEE. Government's success in achieving its broader BEE objectives depends on the willingness and capabilities of companies to implement BEE initiatives. If companies are dissatisfied with the process, such dissatisfaction will jeopardise the ultimate success of the set programme. The research population comprises SMEs, as defined by the National Small Business Act of 1996, which operate within the engineering manufacturing sector. A total of 70 questionnaires were returned; however, after filtering, the number of valid questionnaires that represented the research population was reduced to 41 .

\subsection{Profile Of Respondents}

The profile of the intended respondents was identified as being that of individuals who are charged with making the strategic decisions in an organization. The profile of the respondents was as follows: CEOs, general managers, managing directors $(61 \%)$, directors (32\%) and senior managers $7 \%)$.

In terms of black ownership the distribution of equity was well distributed, with $46 \%$ of respondents having no black equity and 54\% having some black ownership equity in the company. Such a distribution facilitated the comparing of responses between the two groups. $32 \%$ were found to be family businesses - see Table 2 .

Table 2: Profile of respondents in terms of level of black ownership equity and ownership category

\begin{tabular}{|c|c|c|}
\hline Level of Black Equity Ownership & Number of Respondents & Percentage of Total \\
\hline $0 \%$ & 19 & $46 \%$ \\
\hline $0 \%-25 \%$ & 12 & $17 \%$ \\
\hline $25 \%-50 \%$ & 7 & 8 \\
\hline$>50 \%$ & 3 & $\mathbf{1 0 0 \%}$ \\
\hline TOTAL & $\mathbf{4 1}$ & $32 \%$ \\
\hline Ownership Category & 13 & $68 \%$ \\
\hline Family Business & 28 & $\mathbf{1 0 0 \%}$ \\
\hline
\end{tabular}

\subsection{Effect Of BEE Initiatives}

Seventy-eight percent of the companies rated 3 or higher on the question indicating the level to which they are currently affected by BEE. More significantly, zero respondents indicated that BEE was definitely not an important issue, and a total of $88 \%$ responded with a rating of 3 or higher. 
Table 3: Importance of BEE (1=definitely Not, $6=$ definitely Yes)

\begin{tabular}{|l|c|c|c|c|c|c|c|}
\hline \multicolumn{1}{|c|}{ Statement } & $\mathbf{1}$ & $\mathbf{2}$ & $\mathbf{3}$ & $\mathbf{4}$ & $\mathbf{5}$ & $\mathbf{6}$ & $\begin{array}{c}\mathbf{\%} \text { rating } \\
\mathbf{2}\end{array}$ \\
\hline $\begin{array}{l}\text { Q8. My company is affected by } \\
\text { BEE. }\end{array}$ & $7 \%$ & $5 \%$ & $29 \%$ & $15 \%$ & $10 \%$ & $24 \%$ & $78 \%$ \\
\hline $\begin{array}{l}\text { Q9. BEE is one of the most } \\
\text { important issues that a company } \\
\text { has to deal with today. }\end{array}$ & $0 \%$ & $12 \%$ & $32 \%$ & $17 \%$ & $15 \%$ & $24 \%$ & $88 \%$ \\
\hline
\end{tabular}

Figure 1 shows where the pressure to implement BEE is coming from, as per the total sample combined. It indicates that amongst all respondents only 5\% implement BEE in order to expand their markets into the black market. The majority of respondents (53\%) implemented BEE because of pressure applied by customers and $15 \%$ indicated that they implemented BEE in order to secure government business, for which BEE is a requirement. We were able to disaggregate these results further and this conclusion remained irrespective of the level of black ownership or whether or not it was family owned. For example, companies that are family-owned businesses do not think $(0 \%)$ that BEE is implemented in order to gain access to the black market. $77 \%$ indicated that they implemented BEE in response to customer requirement or due to an interest in gaining access to government contracts.

Figure 1: Pressure to Implement BEE (All respondents)

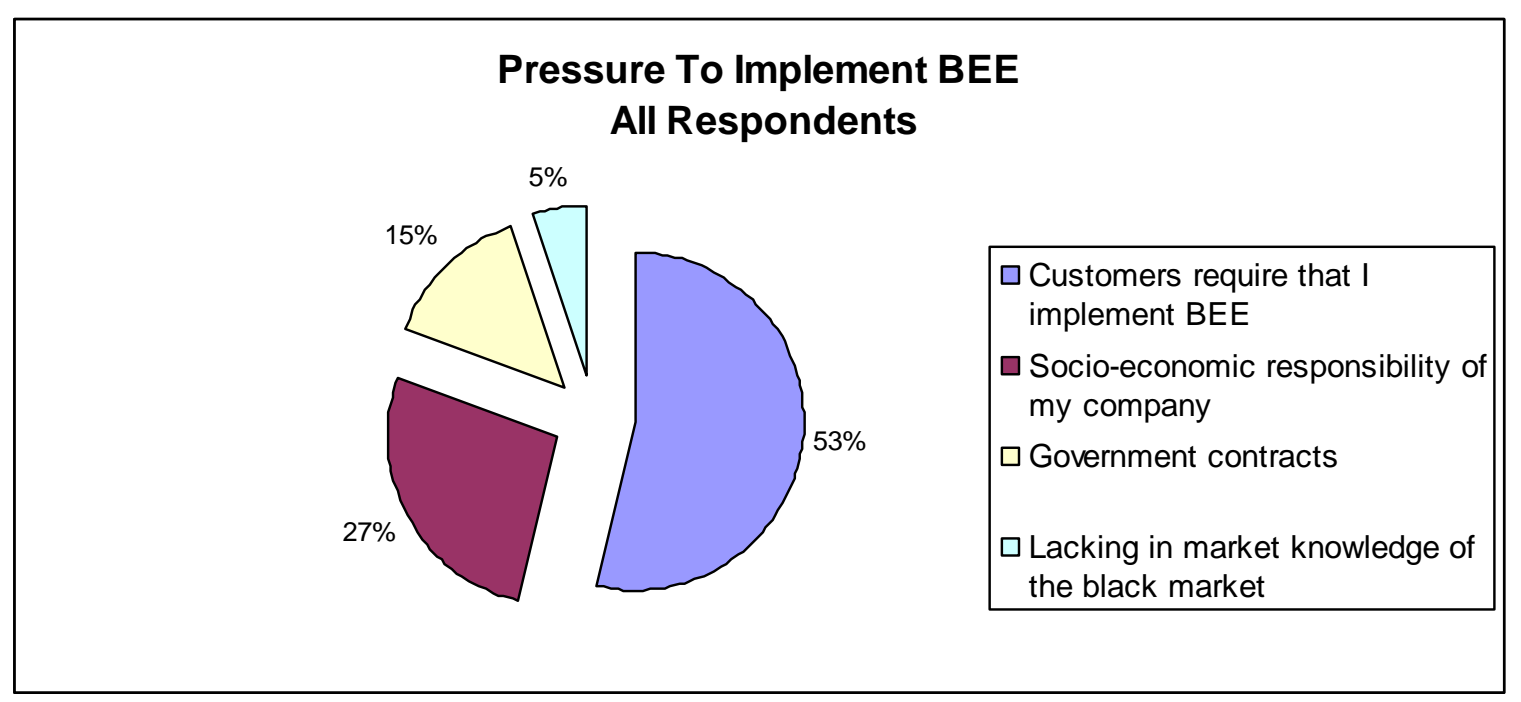

The responses shows that $73 \%$ of SMEs within the engineering manufacturing industry implemented some form of BEE initiative or are in the process of implementing BEE initiatives. Only 5\% of all respondents indicated that they had not implemented BEE and did not intend to implement BEE initiatives. Of the $73 \%$ that have implemented some form of BEE initiative, 38\% have had the BEE initiatives in place for less than a year, 54\% have had them in place for between 1 and 5 years and only $8 \%$ have had BEE in place for more than 5 years. The majority of the industry $(92 \%)$ has had BEE initiatives in place for less than 5 years, which indicates that the two primary pieces of BEE legislation, namely the Preferential Procurement Policy Framework Act (2000) and the Broad-Based Black Economic Empowerment Act (2003), have been instrumental in driving BEE within the SMEs in the engineering manufacturing industry. 
Respondents were asked whether they thought that BEE would be advantageous and, if so, how so. The responses received validated findings that most businesses implement BEE in order to secure existing business or in order to gain access to new business especially amongst government, parastatals and large corporates. Respondents specifically referred to the pressure that was being applied by these institutions to comply with BEE recommendations. An interesting comment that arose was that a by-product was the improved internal relationships, better cohesive working conditions, organizational culture and labour relations that arose through BEE compliance.

\subsection{Rescaling Of Ordinal Data: Results}

A frequency response table for all respondents was used as an input to the distribution-fitting algorithm as outlined in Stacey (2005). The results of the distribution-fitting algorithm indicate a $\chi^{2}$ value of 30.91 , with a probability value $\mathrm{p}$ of 0.9845 - see Table 4 . Using a significance level $(\alpha)$ of $5 \%$ indicates that the $\chi^{2}$ value is not significant.

Table 4: Summary output conversion from ordinal to interval scale

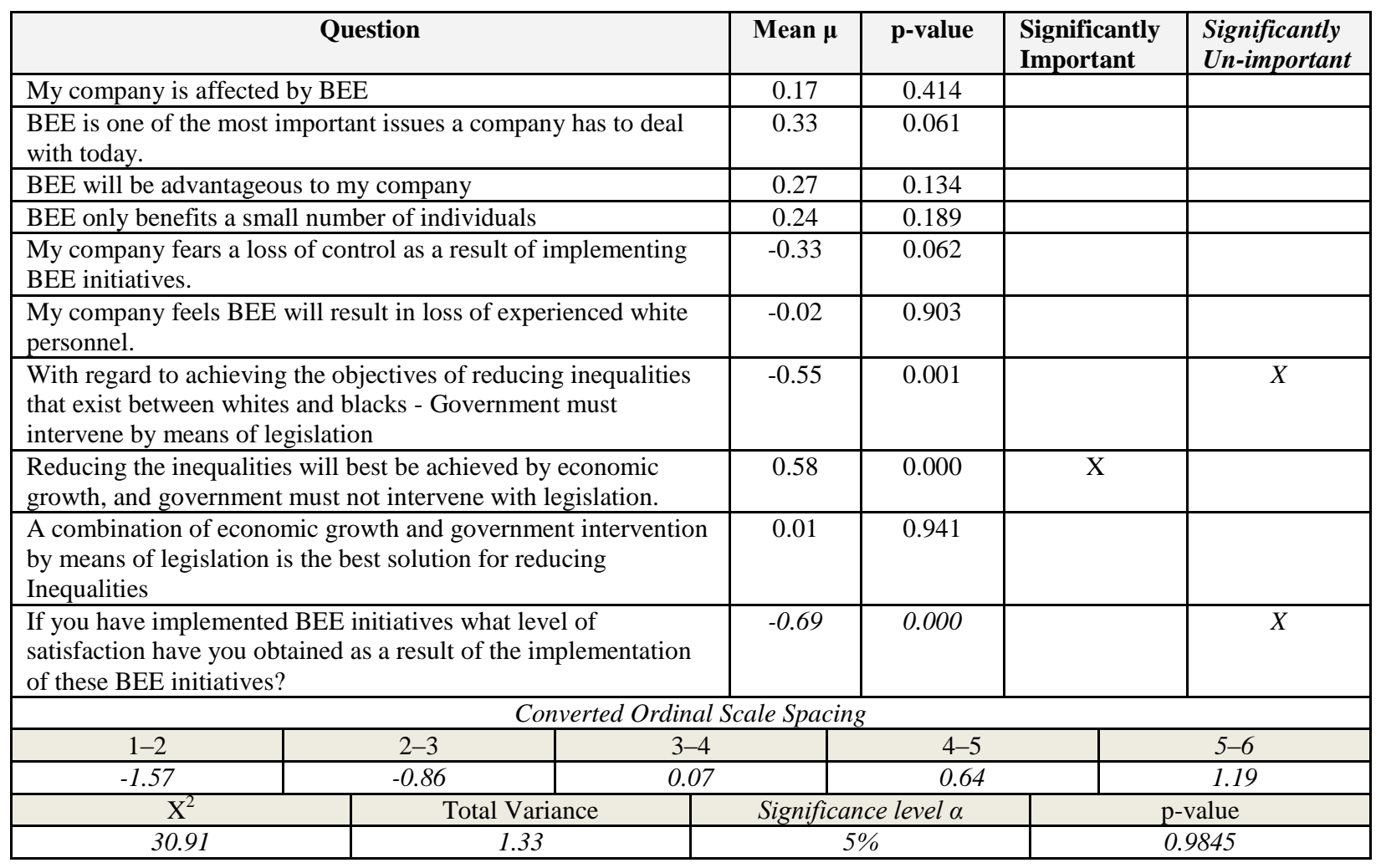

The distribution-fitting methodology that was adopted facilitated the rank ordering of questions. In addition, the threshold between an affirmative and negative response was taken to be the mean of zero, thus a positive mean for this scale was interpreted as being a yes and negative mean was taken to be a no. Whether responses were significantly affirmative or significantly negative relative to each other was determined using the individual calculated probability values ( $\mathrm{p})$. 
A summary of the results are as follows:

- $\quad$ On average, the entire group of respondents felt that BEE was in fact benefiting only a few individuals. The associated $\mathrm{p}$ value of 0.189 indicated that the response was not significantly affirmative.

- $\quad$ Thackwray (1998) proposed that one of the major impediments in the implementation of BEE in South Africa was the attitude of white businesspeople in South Africa. Rabinowitz and Teichner (1998) further added that the reason for their attitude is that they fear a loss of control as a result of implementing BEE. On average, the entire group of respondents felt that, by implementing BEE, they would not lose control of their business and this remained true across race. The associated $\mathrm{p}$ value of 0.062 indicated that the response was not significantly negative; however, it was on the threshold of being considered significant. Clearly, strong opinions were held on the matter. Results indicate that the sentiment towards BEE appears to be divided along ownership category, more than racial, lines with regard to the issue of fear of loss of control. It is understandable that family-owned businesses stand to lose the most, as often their equity has been built up over many years and the original intention was to pass it down through the generations. With most corporate companies, equity is in the hands of various shareholders, so that dilution of equity is not as critical. Often, in such cases, the connection to the business is financial rather than personal.

- $\quad$ The entire group of respondents felt that they would gain a competitive advantage by implementing BEE (mean of 0.27 ). The associated $\mathrm{p}$ value of 0.134 indicated that the response was not significantly affirmative.

- $\quad$ The question as to whether government should intervene by means of legislation to correct economic disparities received a resounding "no response" with a mean of -0.55 . This also proved to be a significant finding with a $\mathrm{p}$ value of 0.001 . The question as to whether disparities would best be removed by economic growth with no government intervention received a resoundingly positive response in terms of the mean of 0.58 , which also proved to be a significant finding. These findings remained true across racial ownership categories. The research has thus shown that companies in the SMEs within the engineering manufacturing sector strongly believe that the growth of the economy should play the most important role in addressing the imbalances between blacks and whites. The findings were significant across all spectra of black equity and family ownership. Sethi (2001) proposed that the sentiment that government should not intervene by means of legislation was predominantly a 'white' business attitude. The research has shown that in the SMEs within the engineering manufacturing industry the holding of such a sentiment is prevalent across the entire spectrum of ownership and is not limited to 'white' business only.

- We were able to identify that all respondents were affected by BEE, in terms of the mean of 0.17 , and that all respondents felt that BEE was an important issue, in terms of the mean of 0.33 . Although none of these responses was found to be significant, the responses were found to be in the affirmative.

A frequency response table for the respondents' responses to 23 statements as they currently reflect the organisational status quo and perceived importance were used as an input to the distribution-fitting algorithm. Tables 5 and 6 contains the summary output from the distribution-fitting algorithm, indicating significance levels and means for the ordinal scale conversions.

The results of the distribution-fitting algorithm indicate a $\chi^{2}$ value of 35.04 , with a probability value $\mathrm{p}$ of 1 . Using a significance level $(\alpha)$ of $5 \%$ indicates that the $\chi^{2}$ value is not significant. The use of the distribution-fitting algorithm to convert the ordinal scale to an interval scale on this set of data, as outlined by Stacey (2005), is justified. 
Table 5: Conversion from ordinal to interval scale for the existing situation for all respondents

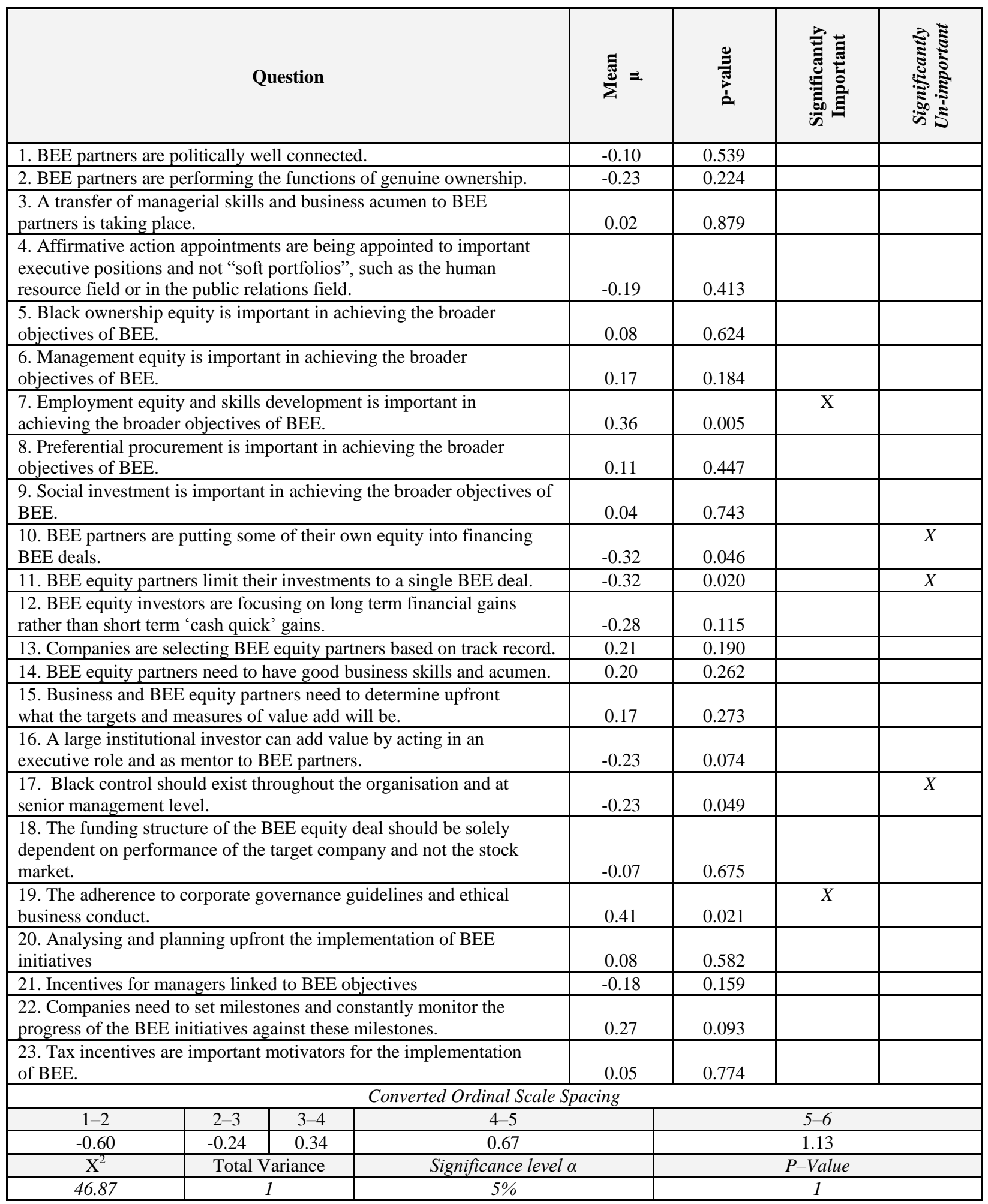


Table 6: Conversion from ordinal to interval scale in terms of the perceived importance of all respondents

\begin{tabular}{|c|c|c|c|c|c|c|c|}
\hline \multicolumn{4}{|c|}{ Question } & 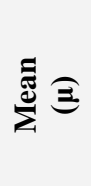 & 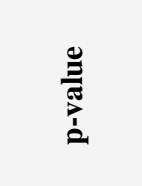 & 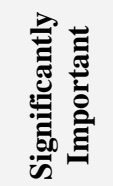 & 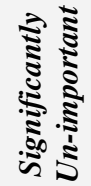 \\
\hline \multicolumn{4}{|c|}{ 1. BEE partners are politically well connected. } & -0.30 & 0.063553 & & \\
\hline \multicolumn{4}{|c|}{ 2. BEE partners are performing the functions of genuine ownership. } & 0.03 & 0.867841 & & \\
\hline \multicolumn{4}{|c|}{$\begin{array}{l}\text { 3. A transfer of managerial skills and business acumen to BEE partners } \\
\text { is taking place. }\end{array}$} & -0.14 & 0.336494 & & \\
\hline \multicolumn{4}{|c|}{$\begin{array}{l}\text { 4. Affirmative action appointments are being appointed to important } \\
\text { executive positions and not "soft portfolios", such as the human } \\
\text { resource field or in the public relations field. }\end{array}$} & -0.20 & 0.206454 & & \\
\hline \multicolumn{4}{|c|}{$\begin{array}{l}\text { 5. Black ownership equity is important in achieving the broader } \\
\text { objectives of BEE. }\end{array}$} & -0.41 & 0.001944 & & $X$ \\
\hline \multicolumn{4}{|c|}{$\begin{array}{l}\text { 6. Management equity is important in achieving the broader objectives } \\
\text { of BEE. }\end{array}$} & -0.08 & 0.505573 & & \\
\hline \multicolumn{4}{|c|}{$\begin{array}{l}\text { 7. Employment equity and skills development is important in achieving } \\
\text { the broader objectives of BEE. }\end{array}$} & 0.18 & 0.141251 & & \\
\hline \multicolumn{4}{|c|}{$\begin{array}{l}\text { 8. Preferential procurement is important in achieving the broader } \\
\text { objectives of BEE. }\end{array}$} & -0.48 & 0.000585 & & $\bar{X}$ \\
\hline \multicolumn{4}{|c|}{$\begin{array}{l}\text { 9. Social investment is important in achieving the broader objectives } \\
\text { of BEE. }\end{array}$} & -0.06 & 0.619307 & & \\
\hline \multicolumn{4}{|c|}{$\begin{array}{l}\text { 10. BEE partners are putting some of their own equity into financing } \\
\text { BEE deals. }\end{array}$} & 0.29 & 0.095842 & & \\
\hline \multicolumn{4}{|c|}{ 11. BEE equity partners limit their investments to a single BEE deal. } & -0.49 & 0.001096 & & $X$ \\
\hline \multicolumn{4}{|c|}{$\begin{array}{l}\text { 12. BEE equity investors are focusing on long term financial gains } \\
\text { rather than short term 'cash quick' gains. }\end{array}$} & 0.13 & 0.480282 & & \\
\hline \multicolumn{4}{|c|}{ 13. Companies are selecting BEE equity partners based on track record. } & -0.08 & 0.629194 & & \\
\hline \multicolumn{4}{|c|}{ 14. BEE equity partners need to have good business skills and acumen. } & 0.64 & 0.004371 & $X$ & \\
\hline \multicolumn{4}{|c|}{$\begin{array}{l}\text { 15. Business and BEE equity partners need to determine upfront what } \\
\text { the targets and measures of value add will be. }\end{array}$} & 0.40 & 0.010906 & $X$ & \\
\hline \multicolumn{4}{|c|}{$\begin{array}{l}\text { 16. A large institutional investor can add value by acting in an } \\
\text { executive role and as mentor to BEE partners. }\end{array}$} & 0.05 & 0.684298 & & \\
\hline \multicolumn{4}{|c|}{$\begin{array}{l}\text { 17. Black control should exist throughout the organisation and at } \\
\text { senior management level. }\end{array}$} & -0.49 & 0.003915 & & $X$ \\
\hline \multicolumn{4}{|c|}{$\begin{array}{l}\text { 18. The funding structure of the BEE equity deal should be solely } \\
\text { dependent on performance of the target company and not the } \\
\text { stock market. }\end{array}$} & 0.21 & 0.164352 & & \\
\hline \multicolumn{4}{|c|}{$\begin{array}{l}\text { 19. The adherence to corporate governance guidelines and ethical } \\
\text { business conduct. }\end{array}$} & 0.46 & 0.012496 & $X$ & \\
\hline \multicolumn{4}{|c|}{$\begin{array}{l}\text { 20. Analysing and planning upfront the implementation of BEE } \\
\text { initiatives }\end{array}$} & 0.37 & 0.015518 & $X$ & \\
\hline \multicolumn{4}{|c|}{ 21. Incentives for managers linked to BEE objectives } & -0.11 & 0.408884 & & \\
\hline \multicolumn{4}{|c|}{$\begin{array}{l}\text { 22. Companies need to set milestones and constantly monitor the } \\
\text { progress of the BEE initiatives against these milestones. }\end{array}$} & 0.24 & 0.127588 & & \\
\hline \multicolumn{4}{|c|}{$\begin{array}{l}\text { 23. Tax incentives are important motivators for the } \\
\text { implementation of BEE. }\end{array}$} & -0.14 & 0.421216 & & \\
\hline \multicolumn{8}{|c|}{ Converted Ordinal Scale Spacing } \\
\hline $1-2$ & $2-3$ & $3-4$ & \multicolumn{2}{|c|}{$4-5$} & \multicolumn{3}{|c|}{$5-6$} \\
\hline-1.43 & -0.98 & -0.34 & \multicolumn{2}{|l|}{0.19} & \multicolumn{3}{|c|}{$\frac{5-6}{077}$} \\
\hline $\mathrm{X}^{2}$ & \multicolumn{2}{|c|}{ Total Variance } & \multicolumn{2}{|c|}{ Significance level $\alpha$} & & $P$-Value & \\
\hline 35.04 & & & $5 \%$ & & & 1 & \\
\hline
\end{tabular}


The analysis of the BEE issues facing SME organisations in the engineering manufacturing industry was facilitated by the use of a perceptual map with the importance rating of issues plotted on the $\mathrm{x}$-axis and the existing situation rating on the y-axis. This essentially created 4 quadrants in which issues were classified as follows: important and being done; important and not being done; unimportant and being done; or unimportant and not being done. The means, as listed in table 5 (importance) and 6 (existing), were used for this purpose. Figure 2 highlights where the individual statements are located in the defined quadrants and also indicates the statements which were found to be significantly important and significantly unimportant based on the $\mathrm{p}$ values obtained.

\section{Less Important Issues - Not Being Implemented}

This is the quadrant that requires no corrective action from industry, as issues not identified as important require no attention. The issues that were identified as falling into this category are listed in Table 7.

Table 7: Issues Identified as Not Important and Not being Implemented

\begin{tabular}{|c|l|}
\hline Number & \multicolumn{1}{|c|}{ Statement } \\
\hline 1 & BEE partners should be politically well connected. \\
\hline 4 & $\begin{array}{l}\text { Affirmative action appointments should be made to important executive positions and not just to 'soft } \\
\text { portfolios'. }\end{array}$ \\
\hline 21 & The linking of incentives for managers to BEE objectives is important in achieving successful BEE outcomes. \\
\hline 17 & Black control should exist throughout an organisation at senior management level as well. \\
\hline 11 & $\begin{array}{l}\text { The more diversified the shareholdings that a BEE equity partner has, the more such diversification is likely to } \\
\text { affect the outcome of any BEE deal negatively. }\end{array}$ \\
\hline
\end{tabular}

Figure 2: Perceptual map of Importance versus existing situation, as reflected in statement ratings

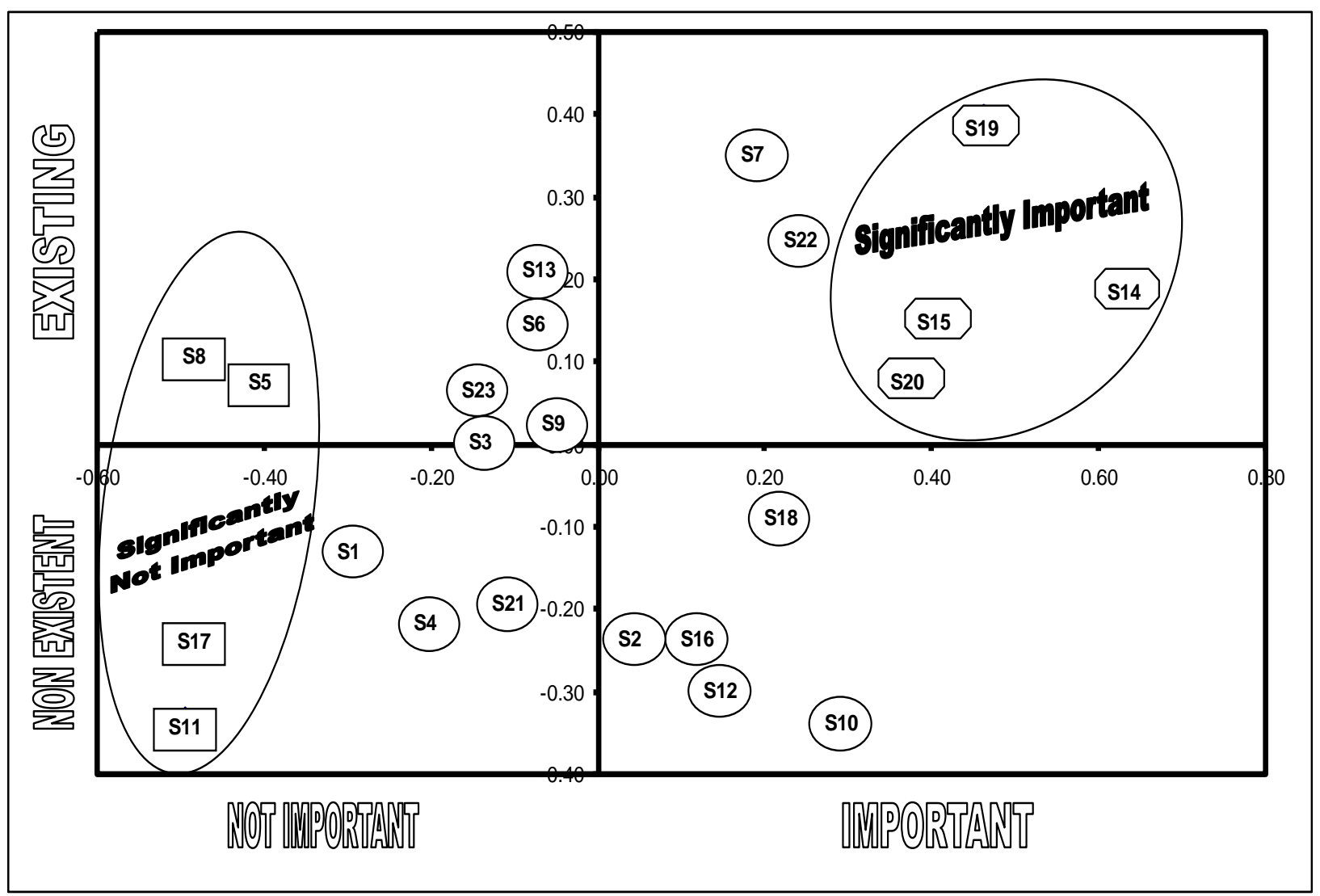


Statements are also discussed in rank order from least unimportant important to significantly unimportant throughout this section.

Incentives for managers linked to BEE objectives ( $\mu=-0.11$ ): The SMEs within the engineering manufacturing sector do not feel that this issue is important in facilitating the transformation process, and, as a result, it is not widely implemented within the sector. Incentives that are not linked to short-term profit generation are very difficult to motivate in SMEs, as the inherent success of such companies often relies on their ability to control costs and expenditure.

Affirmative action appointments should be made to important executive positions and not just to 'soft portfolios' $(\mu=-0.2)$ : Randall (1996) identified fronting and the appointment of black executives to soft portfolios, such as those in human resources, as a potential risk that might lead to the failure of BEE initiatives in the long term. The SMEs within the engineering manufacturing sector do not feel that this issue is important. Of concern, though, is that an element of fronting is occurring within this sector. A potential explanation is that, within the SMEs, structured portfolios and titles are not regarded as important, especially as many family-owned businesses are known to be run by individuals who take on many responsibilities.

BEE partners should be politically well connected $(\mu=-0.3)$ : Guest (2004) identifies that empowerment partners with political connections, have been responsible for creating a 'cronyism' that has wrecked most business in Africa. Our research has shown that this is not perceived to be an important advantage and, as a result, it is not prevalent within the industry. The probable reasoning for this is that within the SME sector deals are not perceived to be lucrative and, as a result, do not attract the attention of political influence.

The more diversified shareholdings a BEE equity partner has, the more likely it is that such diversification will negatively affect the outcome of the BEE deal $(\mu=-0.49)$ : The results indicated that this issue was found to be significantly not important. It also seems that diversified investments by BEE partners are not widespread throughout the sector. A proposed rationale for this is that this particular sector, because of its size, does not attract the large BEE investors and, as a result, the BEE partners who do invest in SMEs within the manufacturing engineering sector are satisfied with a single investment in their portfolio.

\section{Less Important Issues - Currently Being Implemented}

This is the quadrant that needs corrective action unless it is a legislative requirement. Even so, policymakers need to review the effectiveness of policies that fall in this quadrant. From the perspective of the SMEs within the manufacturing engineering sector, unnecessary resources are being spent on issues that are not considered to be important. The issues that were identified as falling into this category are listed in Table 8 below.

Table 8: Issues identified as Less important and Currently being implemented.

\begin{tabular}{|c|l|}
\hline Number & \multicolumn{1}{c|}{ Statement } \\
\hline 13 & Companies should select BEE equity partners based on their track record. \\
\hline 6 & Management equity. \\
\hline 9 & Social investment. \\
\hline 23 & Tax incentives are important motivators for the implementation of BEE. \\
\hline 3 & A transfer of managerial skills and business acumen should take place. \\
\hline 5 & Preferential procurement. \\
\hline
\end{tabular}

Social investment ( $\mu=-0.06$ ): Social investment is one aspect of the B-BBEE scorecard. The rating of this issue by respondents was very close to the threshold of being average; however, because of its negative rating $(-0.06)$ and the consistent application of the classification criteria adopted by the research methodology, it was considered to be a slightly unimportant issue. Nevertheless, SMEs within the manufacturing engineering sector are undertaking social 
investment. Of particular interest is that, although it is not considered an important issue; because of legislative requirements to score well on the B-BBEE recommendations, the sector is, albeit unwillingly, addressing this issue. Likewise with management equity $(\mu=-0.08)$ which is another aspect of the B-BBEE scorecard.

Companies should select BEE equity partners based on their track record $(\mu=-0.08)$ : This issue was found to be unimportant, but very close to falling exactly in the middle of the opinions. Intuitively, one would expect that business people with good acumen would rate this issue very highly, however, one needs to contextualise the responses. A potential explanation for the low importance rating is that discriminatory practices of the past excluded disadvantaged individuals from building a track record; therefore, it would be unfair to apply this selection criterion strictly. As time elapses, the application of this selection criteria is expected to increase as black businesspeople build a track record.

Tax incentives are important motivators for the implementation of BEE $(\mu=-0.14)$ : General intuition in the industry indicates that increased tax incentives would foster the implementation of BEE. SMEs within the manufacturing engineering sector do not believe that this is an important issue to consider.

Transfer of managerial skills and business acumen takes place $(\mu=-0.14)$ : Randall (1996) linked the failure of empowerment initiatives in Kenya and Nigeria to a lack of transfer of skills to empowered individuals but this does not seem to be an issue in this industry.

Black ownership equity $(\mu=-0.41)$ : This is often the most highly emotive issue in SMEs, especially in family-owned businesses that are reluctant to dilute ownership equity. The issue of black ownership equity was rated as significantly unimportant by the SMEs within the manufacturing engineering sector; however, once again because of legislative requirements and the high BEE rating achieved for black equity ownership, the sector is unwillingly addressing this issue.

Preferential procurement $(\mu=-0.48)$ : Preferential procurement is another aspect of the B-BBEE scorecard. This is the most powerful policy available to government, because it cascades down the supply chain, ultimately affecting every business. SMEs are especially vulnerable, as many of the services that they supply are not considered strategic, and it is thought that changing suppliers will not impact on the strategic outcomes of buyers. The SMEs within the manufacturing engineering sector rated this as being the most significantly unimportant issue, probably because of first- hand experience and the pressure that 53\% of their customers are placing on them. Legislative requirements and the ease at which companies can score BEE points without sacrificing control is why the sector is unwillingly addressing this issue.

\section{Important Issues - Currently Not Being Implemented}

This is the quadrant that needs to be addressed urgently, because the SMEs within the manufacturing engineering sector believe that this is important; however, it is not being implemented effectively. The issues that were identified as falling into this category are listed in Table 9 below.

Table 9: Issues identified as Important and Currently not being implemented.

\begin{tabular}{|c|l|}
\hline Number & \multicolumn{1}{c|}{ Statement } \\
\hline 2 & BEE partners should perform the functions of genuine ownership. \\
\hline 16 & A large institutional investor can add value by acting in an executive role and as a mentor to BEE partners. \\
\hline 12 & BEE equity investors should focus on long-term financial gains rather than on short- term 'quick cash' gains. \\
\hline 18 & $\begin{array}{l}\text { The funding structure of a BEE equity deal should solely depend on the performance of the target company } \\
\text { and not on that of the stock market. }\end{array}$ \\
\hline 10 & BEE investors should put more of their own equity into the deal. \\
\hline
\end{tabular}

The issues identified in this quadrant all revolve around the theme of black ownership equity and recommendations as to how equity partners can be more effective as owners of business. 
BEE partners perform the functions of genuine ownership $(\mu=0.03)$ : The results indicate that this is not currently the situation in the SMEs within the manufacturing engineering sector. An explanation for this is that fronting in the industry is prevalent and that the power and control still remain in the hands of the white-owned businesses. Alternatively, the empowerment policy adopted by equity partners are more focused on short-term gains rather than on long-term development.

A large institutional investor can add value by acting in an executive role and as a mentor to BEE partners $(\mu=0.05)$ : The SMEs within the manufacturing engineering sector support this and have indicated that this is not the case within their industry. Government has been putting pressure on financial institutions to provide easy access to capital for BEE equity candidates. The industry has responded well, with all major banks having already established empowerment funds. However, often these empowerment funds provide access to capital for first-time business owners, but then fail in their ability to provide regular support and training to these individuals, who are then overwhelmed with the responsibility of owning a business for the first time.

BEE equity investors should focus on long-term financial gains rather than on short-term 'quick cash' gains $(\mu=0.13)$ : Our respondents indicated that BEE equity partners in their sector are focused on making short-term financial gains. This supports the finding that BEE partners are not performing functions of genuine ownership.

The funding structure of the BEE equity deal should solely depend on the performance of the target company and not on that of the stock market $(\mu=0.21)$ : Our respondents indicated that currently the structure of BEE equity deals is not exclusively linked to the performance of the business unit. As a result, no incentive for BEE equity partners exists to play a more executive role in the business, as shares are converted into equity with no link to company performance.

BEE investors should put more of their own equity into the deal $(\mu=0.29)$ : This is supported by our research. One of the greatest motivators is ownership, thus if equity partners stand to lose nothing if BEE deals go sour, the motivation level to make the deal succeed will not be high. The argument is that often, because of historical disadvantages, BEE equity partners lack substantial capital to put into these deals.

\section{Important Issues - Currently Being Implemented}

This is the quadrant on which SMEs within the manufacturing engineering sector are focusing their energies because of its perceived importance. The issues that were identified as falling into this category are listed in Table 10.

Employment equity and skills development $(\mu=0.18)$ : Employment equity and skills development is the only aspect of the B-BBEE scorecard which has been considered to be important by the SMEs within the manufacturing engineering sector. The reason for this is that it makes business sense in any circumstance to develop the skills within your organisation, and, as a result, the sector is actively developing skills. The introduction of the skills levy and the ability to claim back money for accredited training has also been a main motivator. With regard to the employment equity aspect, often companies find that they reflect the demographics of the country on lower qualification bands; however, on higher qualification bands such demographics are under- represented.

Table 10: Issues identified as Important and Currently being implemented.

\begin{tabular}{|c|l|}
\hline Number & \multicolumn{1}{|c|}{ Statement } \\
\hline 7 & Employment equity and skills development. \\
\hline 22 & $\begin{array}{l}\text { Companies need to set milestones and constantly to monitor the progress of BEE initiatives against these } \\
\text { milestones. }\end{array}$ \\
\hline 20 & $\begin{array}{l}\text { Analysing and planning upfront the implementation of BEE initiatives is important in achieving successful } \\
\text { BEE outcomes. }\end{array}$ \\
\hline 15 & $\begin{array}{l}\text { Business and BEE equity partners need to determine upfront what the targets and measures of value add will } \\
\text { be. }\end{array}$ \\
\hline 19 & $\begin{array}{l}\text { The adherence to corporate governance guidelines and ethical business conduct is important in achieving } \\
\text { successful BEE outcomes. }\end{array}$ \\
\hline & BEE equity partners need to have good business skills and acumen. \\
\hline
\end{tabular}


Companies need to set milestones and constantly to monitor the progress of the BEE initiatives against these milestones $(\mu=0.24)$ : SMEs within the manufacturing engineering sector agree that this is very important for the successful implementation of BEE initiatives. The sector currently is implementing this good practice as it implements its BEE initiatives.

Analysing and planning upfront the implementation of BEE initiatives $(\mu=0.37)$ : The finding was found to be significantly important. It is understandable that SMEs are very reluctant to dilute ownership and control and, thus, if they are going to do so, substantial planning will go into it before implementation occurs.

Business and BEE equity partners need to determine upfront what the targets and measures of value add will be $(\mu=0.40)$ : The finding was found to be significantly important. It is understandable that SMEs are very reluctant to enter BEE deals where equity partners are perceived to be getting a free ride; therefore, the achievements of value add targets form an integral part of BEE deals in the SMEs.

The adherence to corporate governance guidelines and ethical business conduct $(\mu=0.46)$ : Corruption is often the Achilles heel of business in Africa and adherence to strict corporate governance standards is vital to the success of any business. SMEs within the manufacturing engineering sector understandably agree that this is very important.

BEE equity partners need to have good business skills and acumen $(\mu=0.64)$ : The finding was found to be significantly important. SMEs within the manufacturing engineering sector feel that it is important that BEE equity incumbents come into these deals already armed with these skills, and that they do not feel that time should be spent in transferring skills to these individuals after the deal has taken place.

Lastly, we probed the level of satisfaction of respondents who had implemented BEE initiatives. It is important to measure this satisfaction level because this will indicate to policymakers whether or not to modify policies as companies who are satisfied with the BEE transformation in their organisations are more likely to accelerate the rate of transformation. The mean for this question was -0.69 , which indicates that, on average, the entire group of respondents was not satisfied with their BEE initiatives. The response was also found to be significantly negative for all racial and ownership categories which is an area for concern.

\section{Conclusion}

The primary objective of this research was to identify and analyse the relevant issues that SMEs in the engineering manufacturing sector consider important for the successful implementation of BEE. Several significant issues surrounding implementation came to the fore which are summarised below.

BEE partners need to perform the functions of genuine ownership and should focus on long-term financial gains rather than on short-term 'cash quick' gains which seem to be prevalent. The funding structure of the BEE equity deal should solely depend on the performance of the target company and not on the stock market and partners need to commit more of their own capital and expertise into the deal. Large institutional investors can add value by acting in an executive role and as a mentor to BEE partners. Companies need to set milestones and constantly to monitor the progress of the BEE initiatives against these milestones. This in turn requires thorough analysis and planning upfront, as well as pre-determining the targets and measures of value add. It is vital that there is adherence to corporate governance guidelines and ethical business conduct and this should not be compromised for political expediency.

Furthermore, the research found that the primary reason for the introduction of BEE is the need to maintain existing business and in order to enhance the potential to obtain new business. The analysis has shown that such a finding is confirmed across all spectra of ownership. The majority of respondents feel that BEE is not broad-based and that only a few individuals are benefiting from BEE implementation. All respondents indicated that they were not satisfied with the outcomes of the BEE initiatives they had implemented. 
This dissatisfaction has worrying implications for the cost of doing business in South Africa as it implies that BEE is imposing costs which are not delivering the necessary returns. The question is of course whether it will deliver social and political stability for the country as a whole and that remains to be seen.

\section{REFERENCES}

1. Black Economic Empowerment Commission. (2001). Bee Com, Johannesburg: Skotaville Press.

2. Dlamini, F. (2001). Critical Success Factors for Black Economic Empowerment. MBA Dissertation. Johannesburg: University of the Witwatersrand.

3. Easterly, W. (2001). The middle class consensus and economic development. Journal of Economic Growth, December 2001, 6(4): 317.

4. $\quad$ EIU. (2005a). Malaysia economy: Failing to spread the wealth. EIU. New York, 26 August.

5. $\quad$ EIU. (2005b). South Africa Country Fact Sheet. EIU. New York, 21 November.

6. $\quad$ EIU. (2005c). BEE: fact or fiction ?. EIU. New York, 21 September.

7. Guest, R. (2004). The World's most extreme affirmative action program. Wall Street Journal, 23 December: A10.

8. Klitgaard, R. \& Katz, R. (1983). Overcoming ethnic inequalities: Lessons from Malaysia. Journal of Policy Analysis and Management, Spring, 2(3):333-349.

9. Mabert, V.A., Soni, A. \& Venkataramanan, M.A. (2001). Enterprise resource planning: Common myths versus evolving reality. Business Horizons. 44(3): 69-76.

10. Mangaliso, M.P. \& Nkomo, S.T. (2001). HeardBuoys McCann-Ericksons's Chairman Peter Vundla on black entrepreneurs and economic empowerment. The Academy of Management Executive, August, 15(3):16.

11. Masland, T. (2005). A Good life for a few: Critics say economic policies have created a black elite but done little to help the masses. Newsweek, January 24: 38.

12. Osava, M. (2006). Brazil: Correcting centuries of racism against Afro-Brazilians. Global Information Network, 27 July: 1.

13. Rabinowitz, I. \& Teichner, W. (1998). Black Economic Empowerment. M Com research report. Johannesburg: University of the Witwatersrand.

14. Randall, D.J. (1996). Prospects for the development of a black business class in South Africa. The Journal of Modern African Studies, 34(4): 661-686.

15. Robinson, S. (2004). The Second revolution black achievement in business? Yes, please. But a new program to spread the wealth shows how difficult the task is. Time International, 19 April, 163 (16); 42.

16. Sethi, S.P. (2001) The economics of Apartheid: Bringing blacks into business. Business and Society Review, 27-31.

17. Stacey, A.G. (2005). The reliability and validity of the item means and standard deviations of ordinal level response data. Management Dynamics, 14(3):2-25.

18. Thackwray, T.G. (1998). Structures for Black Economic Empowerment in South Africa. MBA research report. Johannesburg: University of the Witwatersrand. 


\section{NOTES}

